This item was submitted to Loughborough's Research Repository by the author.

Items in Figshare are protected by copyright, with all rights reserved, unless otherwise indicated.

\title{
Power as well as Persuasion: political communication and Party development
}

PLEASE CITE THE PUBLISHED VERSION

PUBLISHER

(C) Palgrave-Macmillan

LICENCE

CC BY-NC-ND 4.0

REPOSITORY RECORD

Wring, Dominic. 2019. "Power as Well as Persuasion: Political Communication and Party Development". figshare. https://hdl.handle.net/2134/1093. 
This item was submitted to Loughborough's Institutional Repository by the author and is made available under the following Creative Commons Licence conditions.

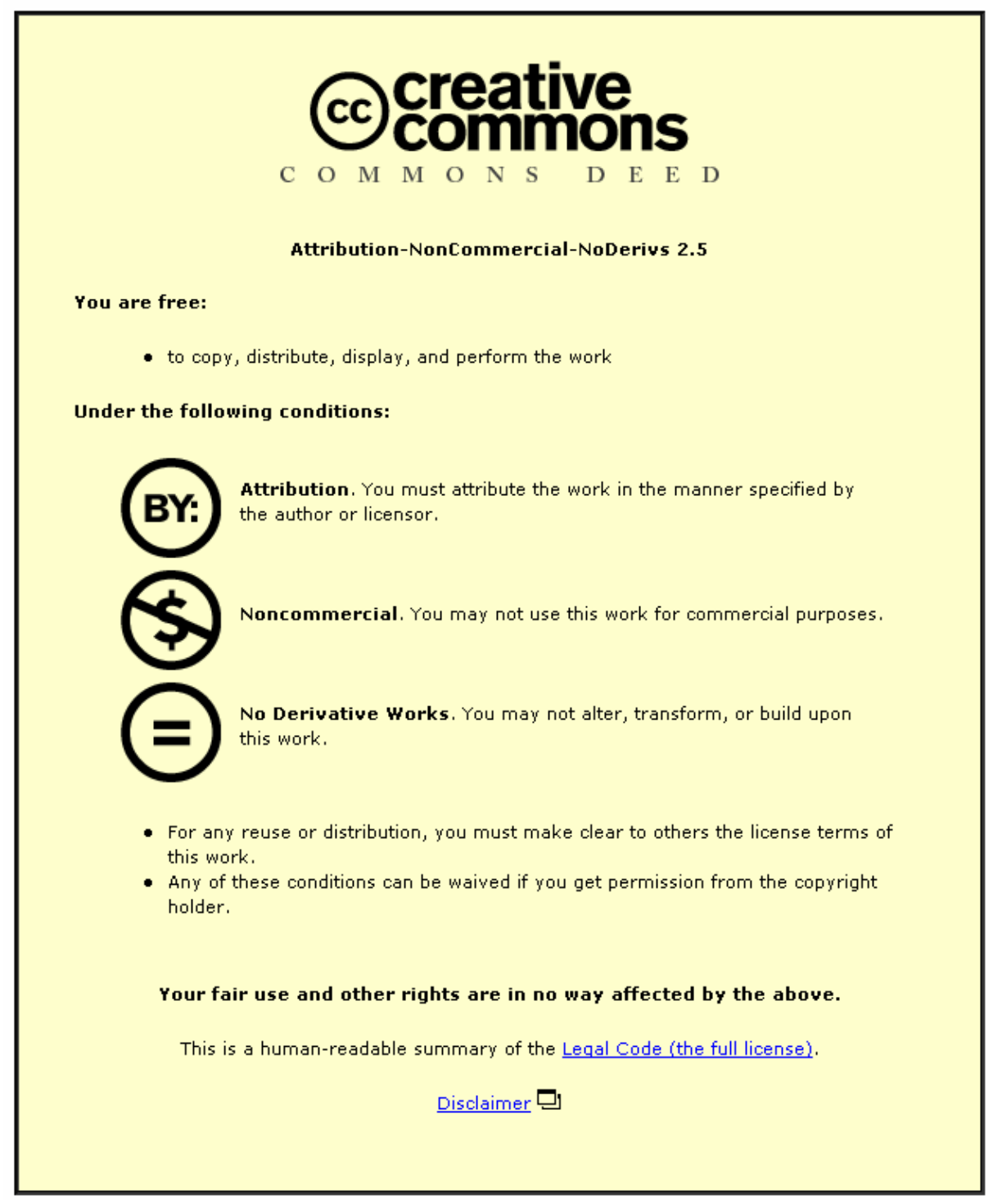

For the full text of this licence, please go to: http://creativecommons.org/licenses/by-nc-nd/2.5/ 
L Loughborough University

Wring, D.(2001)

'Power as well as Persuasion: Political Communication and Party Development', in Bartle, J. \& Griffiths, D.(eds.) Political Communication Transformed, Hampshire: Macmillan-Palgrave. 


\section{Power as well as Persuasion:}

\section{Political Communication and Party Development.}

Dominic Wring

\section{Introduction.}

In the run-up to and during the 1997 general election political discourse was dominated by references to the supposed power and influence of the so-called 'spin doctors' and 'image makers'. These terms are often, and quite erroneously, used interchangeably. Those charged with 'doctoring' the 'spin' are primarily concerned with managing so-called 'free' media which is the coverage given politicians by print and broadcast journalists. Working in tandem with this group, the 'image makers' are those marketing experts charged with interpreting popular opinion and developing a strategy to promote their particular party, candidate or leader by use of 'paid' or 'controlled' communications such as advertising.

By contrast with the 1997 campaign, the 1945 general election was largely devoid of talk about the work of the parties' respective media experts. Nonetheless mass communication did play a role and both Conservative and Labour organisations retained the services of professional publicists. Unlike 1997 however, much of the popular engagement with the electoral process in the 1945 campaign came at grassroots' level. Reminiscing fifty years after the election that marked the beginning of his parliamentary career, former prime minister Jim Callaghan observed: 'I was not conscious of any interference from Transport House (party headquarters). We fought our own election. We were isolated'. ${ }^{1}$

Since the war increased mediation of the democratic process combined with leading politicians' desire to capitalise on this development has transformed the nature of political communication. Once marginal strategists responsible for managing the parties' central campaigns now enjoy a formidable and powerful role within their 
respective hierarchies. Much of the discussion about the consequences of mediated politics has rightly addressed the elusive issue as to the efficacy of professional techniques of persuasion. Most debates have concentrated on these methods' relationship to popular opinion. ${ }^{2}$ Arguably there has also been an important effect at the level of the political elite. Indeed this is not a new concern and is one shared by a range of scholars from Michels to Panebianco. ${ }^{3}$

Party leaderships, eager to adapt and adopt new marketing and media techniques as a means of cultivating voters, have increasingly been using the same methods to manage and police the affairs of their own organisations. Modern political communication is thus inherently concerned with intra-party power relations as well as mass persuasion. This is nowhere more apparent than in the preparation and planning for an election. As Richard Rose observes: 'The activities of campaigning are less concerned with the flow of influence from voters to candidates than they are with the flow within the political parties themselves'.

The opening section of this chapter is concerned with what might be termed 'the communication of politics'. It will assess how election campaigning has evolved over the course of the Twentieth Century and show how changes have been made in response to the enfranchisement of a mass electorate and the challenge of a pervasive mass media. Consideration will also be given to 'the politics of communication', that is the impact developments in campaigning have had on the internal organisation of political parties in Britain. Discussion will focus on the ways in which strategic change has tended to result in the further centralisation of power within parliamentary leaderships and their agents.

The Communication of Politics: the Transformed Campaign. 
Each Nuffield study is an important social document that enables researchers to understand and assess how various political phenomena have evolved since the war. The books remain central to the understanding of how election campaigning developed during this period. The 1945 general election, the subject of the first study, is perhaps more important as a landmark political event than as a watershed in communications' terms ${ }^{5}$. This is because the campaign, held in the aftermath of such a major conflict, was in many ways highly atypical by Twentieth Century standards. Similarly the elections of 1950, 1951 and 1955, called at short notice and fought by relatively poorly resourced parties, provided few opportunities for strategic innovation. ${ }^{6}$ Thus there is a need to look beyond 1945 and the immediate post-war era as the starting point for analysing how party campaigning has evolved over time. Consequently changes in organisation both before and after this period need to be considered.

Several commentators have discussed the transformation of party political communication. A growing consensus appears to endorse the view that there are three principal periods of evolution. The introductory chapter of this volume has labelled them the 'Morrisonian', 'Wilsonian' and 'Mandelsonian' eras. Similarly Farrell $^{7}$ and Norris $^{8}$ have identified and discussed their own three stage developmental models of campaigning whilst Blumler and Kavanagh note the dawning of the 'third age of political communication'.' Adapting a framework popular in commercial marketing, Shama highlighted the parallels between an electoral and a business strategy. ${ }^{10}$ By using this approach together with terminology more relevant to political communication, it is possible to distinguish three key evolutionary periods of electioneering. These are the eras of mass propaganda, media campaigning and political marketing. ${ }^{11}$ The essence of this model is that it places greatest emphasis on the nature of the interactions between an organisation and its audiences. Critically it is this relationship, rather than any particular media or 
technological developments, which is central to identifying how election campaigning has developed and changed over time.

\section{The era of mass propaganda.}

In Britain the era of mass propaganda began in earnest following the introduction of universal suffrage in 1918. Prior to then campaigns had tended to be dominated by what Ostrogorski called a 'trilogy of action' which consisted of the stump meeting, canvass and leafleting. ${ }^{12}$ During the general election year of 1910 the Conservatives managed to distribute 50 million items of literature, the Liberals 41 million and the infant Labour organisation a respectable 6 million. ${ }^{13}$ But a key event was the Representation of the People Act, implemented at the end of the Great War, which nearly trebled the electorate and gave some women and guaranteed working-class men the vote. This landmark legislation, combined with the development of new mass media forms such as radio, meant that, in future, elections would be fought in a context where mass communications could and would play an important role.

The mass propagandist approach, which was prevalent up to the end of the 1950s, can be characterised by the essentially unidirectional flow of information from politician to voter. The party elites promoted their messages to the populace in the straightforward belief that maximum exposure for a message would heighten its appeal. The era of propaganda did, however, witness some important experimentation in terms of political communication. The inter-war period, in particular, saw the major parties first attempts to use radio in the elections of 1924 onwards. ${ }^{14}$ Conservative leader Stanley Baldwin proved to be a particularly effective and popular broadcaster. The potential presented by film, the visual precursor to television, also excited the Conservatives and, more belatedly, Labour. ${ }^{15}$

Anticipating the arrival of public opinion polling, several party strategists began talking about the 'psychology of the electorate' during the 1920s. In an influential 
1922 article, leading intellectual and Labour strategist Sidney Webb mapped out what he termed 'stratified electioneering'. ${ }^{16}$ Webb outlined how parties might profitably promote themselves to target voters distinguishable by their 'colours', that is their social status, partisanship (or lack of it) or whatever. These, he argued, made it possible to identify specific kinds of elector from the overall 'grey' of mass democracy. Leading party official Harold Croft promoted Webb's idea in his popular Handbook of Party Organisation and several organisers sought to operationalise the concept. ${ }^{17}$

The absence of formal market research did not prevent politicians from cultivating links with professionals working in the advertising industry. The Conservatives' intention to use an agency in 1923 was postponed until 1929 when the party's Central Office hired the services of the Holford Bottomley company and another leading firm, SH Benson. ${ }^{18}$ Benson's, soon to gain fame for their legendary Guinness stout advertising, did not do so well in their first election. The agency helped produce posters and other ephemera based on the chosen theme of 'Safety First'. This campaign could not, however, prevent Labour from taking minority office for only the second time. Nevertheless the relationship between Benson's and Central Office developed into an enduring one and lasted for the two further general elections held before the outbreak of war.

Labour for its part was far more circumspect about using advertising agencies and a plan to retain one in 1935 was shelved. As that election proved to be one of the most capital intensive of all time, political considerations rather than cost seem to have militated against the organisation's use of professional expertise. Indeed, the party's pre-election 'Victory for Socialism' campaign raised a creditable $£_{\mathrm{N}} 8000$. Labour did nonetheless continue with its policy of commissioning highly effective and ingenious copy from design artists like Gerald Spenser Pryse and John Armstrong, creator of the famed 'Now Win the Peace' poster in 1945. In 1924 a 
highly attractive logo, the 'Liberty' badge, was approved. ${ }^{19}$ One senior party figure, Herbert Morrison, did however develop contacts in the marketing industries. Through his publicity work as leader of London County Council from 1934 onwards he managed to build up a formidable group of advisers. Several of the professionals took time off from their agency work and became involved in preparations for Morrison's 1937 re-election campaign. ${ }^{20}$ Their expertise was used to good effect and Labour won a further term following a campaign which one trade journal even acclaimed as having 'set the standard' for commercial marketers.

Labour's reticence to embrace methods of mass communication can in part be explained by organisational factors such as poor finances and general inertia. Unlike the Conservatives, the party contained a strong body of opinion critical of what were perceived to be irredeemably capitalist activities like marketing. Commentators have sometimes overlooked these sentiments and assumed Labour's opposition to professional communications' methods stemmed from Luddite distrust of technology. Rather this distrust is rooted in the early party's doctrinal attachment to education as a means of emancipation. This approach is associated with pioneering socialist propagandist Robert Blatchford, publisher of the Clarion journal. He famously spoke of his desire to 'Make Socialists'. Consequently Labour tended to favour direct, didactic or 'educationalist' methods over what were perceived to be the more shallow, mass mediated forms of political communication.

Those critical of Labour's educationalist stance during the inter-war period argued many lay people were invariably uninterested in politics yet needed to be won over if not converted by Labour. Such a view found support from Graham Wallas, a Fabian thinker and London School of Economics academic. In his book Human Nature in Politics, he questioned the classical democratic assumption that the electorate was a deliberative body of opinion capable of making informed choices and argued that most voters knew little of politics. ${ }^{21}$ As a consequence he argued 
that the best way of communicating with them would be through advertising and other image conscious media. Evidently some of his fellow Fabians took the message of Wallas' work seriously when they organised an 1936 Society conference on the theme 'Selling Socialism'.22 Indeed, as the example of London County Council's Herbert Morrison indicates, a few people within the party were keen to embrace more image conscious approaches to political communication.

\section{The rise of media campaigning.}

In the couple of decades following the Second World War two particular changes in the media had a profound impact on political communication in Britain. The growth of popular televison, most notably between the 1955 and 1959 elections, combined with the pioneering, investigative style of the new Independent Television News (ITN) organisation forced the parties to think about how they might exploit the opportunities mass visual broadcasting now afforded them. ITN formed part of the independent network. ${ }^{23}$ This new service was funded from advertising revenues. The marketing industry rapidly expanded in size and influence, giving rise to what cultural commentators termed the 'consumer society'. Political parties would not be immune to the new commercial ways of doing things.

In their study of the 1959 Conservative victory, the Nuffield authors acknowledged the electoral importance of the new commercial media environment when they prominently highlighted Lord Woolton's observation that 'the voter is also the consumer' at the head of an opening chapter. ${ }^{24}$ Indeed, it was this election which showcased the emergence of what can usefully be termed the 'media campaign'. Unlike the primarily unidirectional (party to voter) propagandist technique, this approach emphasised the need to solicit feedback through the use of public opinion research in order to better refine and redefine political presentation. Greater attention was paid to the promotion of the party image, particularly through the new 
televisual medium. Professional marketing techniques and personnel began to become integral to the functioning of campaign organisations.

Clearly influenced by his co-authoring of the 1959 Nuffield study and contribution to the following instalment, Richard Rose went on to complete Influencing Voters, his seminal study into the emergence of media campaigning in Britain. ${ }^{25}$ Central to this analysis was a more managerialist conception of electioneering. Thus reference was made to various constituent parts of a campaign such as the competitors, client, environment, rules and strategy. Scholars like Rose and former Conservative advertising strategist David Hennessy (ennobled as Lord Windlesham) joined David Butler and his fellow Nuffield authors in helping to foster the view that party political communication was a potentially rich and important arena for study and analysis. $^{26}$

The Conservatives' reinvention of themselves as a campaign organisation following their landslide defeat in 1945 was painstaking and incremental. By 1948 the party's Central Office headquarters had established a Public Opinion Research Department devoted to the study of voter attitudes. ${ }^{27}$ With help from the Conservatives' newly appointed advertising agents Colman Prentis Varley (CPV), the PORD embarked on an assessment of voter attitudes which culminated in a major report called The Floating Vote. The document, a wide ranging survey based assessment, identified several groups of potential supporters such as young people, women, Liberal supporters and weak partisans. But it was the following decade, in the run up to the 1959 election which provided a showcase for the new, professionalised methods of communications. CPV played a central role in the long run-up to the campaign. Research and advertising expertise resulted in them producing the celebrated image of nuclear family emblazoned with the slogan 'Life Better Under the Conservatives: Don't Let Labour Ruin It'. ${ }^{28}$ Victory followed. The electoral performance of the 
Conservatives reinforced the perception that effective political communication could be a determinant of success.

Initially sceptical about the value of the new media approach, many Labour strategists were weary of committing resources to an advertising process many viewed with hostility. Nevertheless in the intervening years between the 1959 and 1964 elections, the party reorganised its campaigning. ${ }^{29}$ A key feature of the changes was Labour's preparedness to engage and use marketing expertise in the guise of public relations, opinion research and advertising consultants. The 1964 election and its outcome meant the return of the party to government. The result once again helped propagate the view that good political communication could be an important element of this narrow victory, particularly in a tightly fought contest.

In embracing the new, more media driven approach to campaigning it is perhaps surprising the party did so under the leadership of Harold Wilson. Wilson had originally been an educationalist critic of colleagues who he accused of wanting to 'refashion the Labour Party as the British version of the US Democratic Party'. ${ }^{30} \mathrm{He}$ was by no means alone in adopting such a view. Yet within a few years and, having been elected leader, Wilson proceeded to oversee an important transformation in his party's approach to political communication. This electoral success brought support for the kind of changes he would have once attempted to thwart. Yet many within the party hierarchy remained unhappy about the increasing political role and use of professional marketers. At the 1978 Michael Foot mocked the Conservatives for their reliance on the Saatchis. During the subsequent campaign Labour leader James Callaghan prided himself on declaring that he, unlike his principal opponent Margaret Thatcher, would not be sold like 'Daz or Omo'. ${ }^{31}$

The development of political marketing. 
The 1966, 1970 and 1974 general elections all saw slight variations and modifications to political communication. The 1979 campaign, however, was qualitatively different. This change was partly brought about by the groundbreaking strategy of the winning party, the Conservatives. ${ }^{32}$ The notion of this as a watershed election was also reinforced by a number of environmental factors. Most notable of these was the perception that there had been a marked rise in voter volatility as suggested by the apparent decline in support for the two major parties over the course of the previous decade. The notion that electoral behaviour might increasingly come to resemble a commercial market in flux appeared to be becoming more than just an analogy. Voters, it was argued, were becoming less fixed in their allegiances and more prone to shop around for the the most attractive party offering. ${ }^{33}$

In tandem with the theoretical re-evaluation of voter behaviour came a marked intensification and interest in the use of marketing methods, a trend reinforced during the early 1980s with the rapid growth of the UK's service industries. Central to this development was the growing importance and influence of modern managerialism in its various guises including the marketing communications sector of public relations, advertising and market research. The combined impact of these methods and approaches has resulted in the commodification of all aspects of public life. Politics has not been immune. The mediation of the democratic process has also encouraged this trend because changes in broadcast and print journalism have afforded more reportage of key events and thereby enhanced the promotionalism of civic life and current affairs more generally.

The Conservatives' successful campaigns in 1979 and 1983 are generally regarded as having ushered in the new era of marketing driven politics whereby opinion researchers and professional marketeers became increasingly central to strategic deliberations. The partnership between Margaret Thatcher, the advertising agency owned by the two Saatchi brothers and their business colleague Tim Bell made for a 
formidable team. Thatcher, a keen student of political opinion polling, was regarded as a conviction politician. The private regard she showed her marketing advisers was not publicly afforded her parliamentary colleagues. She maintained a keen interest in the management of the party's communications and saw it as central element of her own appeal. ${ }^{34}$

Scammell reconciles the apparent disparity between Thatcher the conviction politician and her advocacy of marketing by noting how she allowed research to influence the tenor and boundary of policy. Critically, the Thatcherite project used opinion polling but also took advantage of several environmental opportunities. ${ }^{35}$ Consequently economic circumstances, rising concern over crime, a supportive print media, a divided opposition and other factors were all exploited in a highly strategic manner.

In contrast to the Conservatives the oppositon parties were uneasy with the new communications techniques. The cost of using professional methods combined with ideological criticisms combined to limit the Liberals and Labour's adoption of marketing techniques and personnel. Nevertheless in the early 1980s the newly founded Social Democratic Party did recoup its investment in direct mail by using it to successfully raise funds and recruit members. ${ }^{36}$ This approach soon became a key element of Conservative organisation. Before the end of the decade Labour too was displaying its commitment to the potential power of good communications. Hence during the 1987 general election, the party's conscious use of advertising and public relations showcased its belief in image management.

The 1992 general election marked arguably a major turning point in modern campaign history. This is because both of the major parties contending for office had now embraced political marketing as a strategic approach. Labour, having repositioned itself to the right following its polling saturated Policy Review, fully 
integrated advertising, market research and public relations into the headquarters' electoral organisation. In the aftermath of the 1983 general election defeat Robin Cook had formed a contact 'breakfast' group of sympathetic professionals to help advise on campaign strategy. ${ }^{37}$ In 1986 the new Shadow Communications Agency (SCA) deepened the emryonic links between the party and marketing industries. The SCA functioned by allowing Labour supporters working in the business to offer their skills and expertise on a voluntary and anonymous basis. Their charity combined with a lively and creditable performance in the 1987 general election promoted the importance of political marketing throughout the party. ${ }^{38}$ By 1992 marketers such as the SCA co-ordinator Philip Gould and his colleague Deborah Mattinson enjoyed unprecedented positions of influence within the hierarchy surrounding leader Neil Kinnock. Despite a fourth defeat and the disbanding of the SCA by Kinnock's successor John Smith, marketing personnel and ideas continued to play an important strategic role thereafter.

The Conservatives once again employed the Saatchi agency in preparing for the 1992 campaign. Marketing personnel worked closely with the Central Office bureaucracy. Problems for them included the difficult economic situation and the potentially uncomfortable issue of Margaret Thatcher's resignation 18 months before in November 1990. The personality of John Major, then regarded as a considerable asset, became central to his party's efforts. Major's interest in sport and perceived qualities of affability and modesty were a key advertising theme along with his profile as a world statesman. ${ }^{39}$ The presidential approach was supported by a public relations gimmick, the soap box. A response to the allegedly synthetic selfpromotion of his Labour opponent, several journalists saw an attempt by Major to play down the importance of so-called 'image makers'. ${ }^{40}$ Yet image management was precisely what the Prime Minister was engaged in. The key marginal seats of Bolton and Luton Major visited in his soap box appearances suggested careful preparations had been made for what were opportunities to manufacture good television pictures 
rather than to speak directly to voters. The Conservative leader's efforts thus resonated with a mediated political tradition of the 'people's champion' stretching from the Hollywood film 'Mr Smith Goes to Washington' through to Boris Yeltsin's famous public denunciation of the 1991 Soviet coup from the top of a tank.

The public goodwill towards the Conservatives evaporated not long into the 1992 parliament. In September that year the government was forced to withdraw the United Kingdom from membership of the European Exchange Rate Mechanism. The ERM crisis, which cost the country billions of pounds, seriously undermined voter confidence in John Major and his party. It never returned. Following John Smith's sudden death in 1994 a marketing conscious Labour opposition elected Tony Blair to the leadership. Blair had been the candidate most favoured by polls of the electorate. The youthful leader subsequently rewrote his party's Clause 4 mission statement and rebranded the party 'New' Labour. Blair kept up the already remorseless pressure on a beleaguered and unpopular government. SCA veterans Philip Gould and Chris Powell together with the latter's BMP DDB Needham agency co-ordinated the party's marketing efforts. Along with the rest of the bureaucracy, the campaign team relocated to Labour's new Westminster based headquarters housed within the Millbank building. Here strategists co-ordinated polling and focus group research and discussed tactics. ${ }^{41}$ Those in charge were aided by a new rapid rebuttal service, the so-called Excalibur database, donated to the party by wealthy supporter Philip Jeffrey. The efforts of Millbank together with a series of self-inflicted Conservative wounds combined to give Labour a landslide victory.

\section{The Politics of Communication: the Transformed Organisation.}

The increased professionalisation of political communication has been motivated by party strategists' desire to best promote their case to a mass electorate. The 
transformation of campaigning may have had some effect on voters but what is more readily demonstrable is the impact these changes have had on the organisations themselves. With the 'marketisation' of electioneering over the course of the Century there have been important changes in the internal structures of the party organisation involved.

\section{Conservatives: from gentleman to players.}

In 1910 Sir Malcolm Fraser became the first Conservative official to hold a publicity brief. The following year saw the establishment of a party Press Bureau. ${ }^{42}$ Enthusiastic support from most of the major privately owned national newspapers made the job straightforward. Fraser's role was to keep sympathetic journalists supplied with useful information not least about the plans and activities of the Labour and Liberal opposition. The links, even collusion, between Conservative Central Office and the Fleet Street print media were the subject of some controversy during the 1924 general election. The first to be fought by an incumbent Labour administration, the campaign ended in the party's ejection from government. This followed the publication of the so-called 'Zinoviev Letter' in the right-wing Daily Mail just before polling day. ${ }^{43}$ The paper's story, which alleged the Soviet Union strongly supported Labour's re-election, provoked outrage from a party fearful of guilt by association. Subsequent revelations suggested the letter was a forgery concocted by a conspiracy involving Conservative officials, selected journalists and MI5 agents. Whatever the origins, the incident hinted at the potential power and usefulness of the so-called 'Tory Press'.

Conservative campaigning took a qualitative turn with the appointment of JCC Davidson to the key organisational portfolio of Chairman in the 1920s. ${ }^{44}$ A key feature of his tenure was the rejuvenation and use of a more aggressive publicity machine. Davidson received help from the former secret service agent Joseph Ball. Ball prepared the party for the 1929 election and went on to be instrumental in 
forming the National Publicity Bureau, an ambitious departure from the usual publicity machinery which took in the advice of various strategists. Part of this venture involved the organisation of various communications and an ambitious programme of film propaganda that was popular with the public. A Conservative Film Association headed by Sir Albert Clavering supported this incursion into visual political communication.

Following the war a major rethink and reorganisation of the party took place. These changes culminated in the party's adaption and popularisation of the media type campaign. The young John Profumo began work with Central Office as broadcasting officer and visited the United States to observe the election campaign of $1952 .{ }^{45}$ In tandem with this the so-called 'Radio Doctor' Charles Hill popularised his party's use of radio with some PEBs. In the late 1940s the party also recruited the services of the agency CPV and the PORD was set up as part of the reorganisation. The publicity team at Central Office assiduously incorporated the advice of the marketing professionals while simultaneously working to senior figures in the parliamentary leadership.

Many of the Conservatives who lobbied for the creation of ITV were keen to exploit the public relations opportunities afforded by the new medium in order to promote the party through televisual broadcasting. ${ }^{46}$ Crucial to these developments were key strategists like RA Butler MP, a keen supporter of the PORD, and Lords Poole and Woolton. Having commercial backgrounds the two peers were especially keen to use established management practices in the organisation of campaigning. Their confidence in such techniques appeared to be vindicated by the result of the 1959 general election. In preparing for this campaign a Liaison Committee had acted as both conduit for information and main decision-making forum for politicians, officials and consultants. ${ }^{47}$ Though the party continued to employ an advertising agency throughout the decade, more traditionally minded publicity officials were less 
than convinced about more modern approaches to presentation. The organisation was forced to examine its communications' strategy following electoral setbacks in 1964 and 1966.

In 1970 something new was tried and the party retained a group of voluntary advisers. It was an approach directly modelled on that devised by Richard Nixon's aides for his successful 1968 bid to become US president. Ted Heath, the leader, was aided by party official Geoffrey Tucker together with marketing specialists and film makers including Barry Day and Bryan Forbes. ${ }^{48}$ They concentrated on promoting Heath's image and also courting key sections of the public. Women were identified as a particularly important target group. In the ensuing election Heath and the Conservatives won re-election following a closely fought campaign which once again suggested professional political communication might have played some role in aiding the victors.

Heath only enjoyed a single term as prime minister. Like his patron, Tory Director General Michael Fraser's nemesis proved to be Margaret Thatcher. Fraser departed his post not long after Thatcher's election as leader in 1975. The vacancy created was not filled. Instead, Thatcher sought to forge deeper organisational links with external advisers, most obviously the Saatchi and Saatchi brothers and their colleague Tim Bell. Together with Central Office official Gordon Reece the three advisers became central in the planning of the Conservative campaign victories in 1979 and 1983. Eventually the party Chairmanship, a position in the gift of the leader, also went to people more in keeping with the Prime Minister's thinking such as Cecil Parkinson and Norman Tebbit.

Initially the Saatchi agency's partnership with the Conservatives proved mutually beneficial. Strain in the partnership developed following Tim Bell's unhappy departure from the company in the mid-1980s. By the time of the 1987 election 
Chairman Tebbit was working with the Saatchis whilst Thatcher was simultaneously being briefed by Bell and the advertising executive John Banks. During the campaign a rogue opinion poll published a week before voting suggested Labour could win the election. The news led to panic at Central Office on the so-called 'Wobbly Thursday'. Rival strategists argued with each other over the direction of the campaign. The Conservatives went on to win but the serious row within the party further highlighted the prominent and powerful role now played by professional marketing and media advisers.

The promotion of John Major to the Conservative leadership initially unified the party. Victory in the 1992 election consolidated his position. There was, however, a perception that the result had little to do with a negative, fractious campaign. Major's beleaguered administration suffered continual setbacks throughout the 1992 parliament. In the circumstances it was not perhaps surprising that he failed to effectively project a favourable image of himself or his government. Opportunities for good communication were limited by a succession of pressing and difficult political problems. The Saatchis continued to advise the party. Yet the political problems the party faced in approaching the 1997 general election made effective planning and preparation difficult. In the event the Conservatives' efforts lacked conviction. Besides the Saatchi executives, politicians such as Deputy Prime Minister Michael Heseltine and Chairman Brian Mawhinney devised and authorised copy for advertising campaigns that did little to effectively promote the party. The heavy electoral defeat that followed has led to a serious re-examination of party goals and organisation under a new leader, the former management consultant William Hague.

\section{Labour: from Committees to Cabals.}

Following its incarnation as the Labour Representation Committee at the turn of the Century, the Labour party formally fought its first general election six years later in 
1906. An ad hoc committee of leading figures led by Ramsay MacDonald oversaw the development of the campaign organisation. Similar arrangements were made for the two elections held in 1910. MacDonald worked with a small headquarters team based in the Victoria area of London. Major changes came in 1917 with preparations for an overhaul of structures as part of the ongoing re-write of the constitution which culminated in the publication of a new statement of aims and values (the so-called 'Clause Four') the following year. Herbert Tracey was appointed the first ever official to hold the publicity portfolio. Former mill worker Tracey had trained and worked as a journalist. Reflecting his spiritual beliefs, this Methodist lay preacher had been a correspondent with the Christian Commonwealth newspaper. If former military and intelligence personnel dominated appointments to the Central Office publicity machine, those from religious backgrounds were prominent within the Labour operation. This difference perhaps embodies something about the two parties' contrasting approaches to political communication during the inter-war period.

William, the son of leading MP Arthur Henderson, held the publicity job after Tracey's departure in 1921. He remained in charge for over twenty years and right up until the end of the Second World War. Henderson's successor as head of publicity Arthur Bax maintained a fairly low profile. Bax's replacement, the journalist and Gaitskell aide John Harris, proved to be quite different. Harris, supported by a new deputy Percy Clark, facilitated a wholesale review of communications following his arrival at headquarters in $1962 .{ }^{49}$ The death of his patron and former employer Gaitskell did not hinder this work. Indeed, the new leader Harold Wilson keenly supported developments. Wilson, himself a noted student of organisation, famously chaired the committee whose 1955 report accused Labour of having 'a penny-farthing machine'. On assuming the leadership in 1963 he set about helping to remedy these apparent shortcomings by supporting what 
amounted to the largest changes in campaigning structures since those introduced in the immediate aftermath of the Great War.

Prior to 1962 Labour had made some attempts to modernise its approach to presentation. During the 1940s and 1950s future ministers like Patrick GordonWalker and Tony Benn had first come to prominence through their work developing the party's use of radio and television broadcasting opportunities. Benn had hosted a celebrated series of innovative Party Election Broadcasts during the 1959 election campaign. ${ }^{50}$ After the campaign a group of party sympathisers commissioned market researcher Mark Abrams to undertake a survey of popular political attitudes. The influential work which emerged from this, the book Must Labour Lose?, helped raise awareness as to the potential benefits of polling. ${ }^{51}$

By 1964 the party had completed what the Nuffield authors pointedly referred to as 'The Modernisation of Labour'. ${ }^{52}$ A key feature of this process was the work of Harris, Clark and a new grouping of advisers drawn from commercial advertising, market research and public relations' backgrounds. These included aides like David Kingsley and Michael Barnes whose original offers of help had been refused in 1959. Their work on the successful 'Let's Go' campaign helped return a Labour government and also reinforced the view that good communications were now becoming an integral part of electoral success.

The Labour victory was followed by a more resounding success in the 1966 election. The campaign was organised by the same strategists. ${ }^{53}$ The formidable partnership forged between these strategists and the new prime minister led to some of them joining Wilson's controversial 'kitchen cabinet'. The charge of presidentialism levelled at the Labour premier for his maintenance of such an entourage drew considerable criticism. These attacks reached a crescendo following the government's loss of office in the 1970 election. ${ }^{54}$ This defeat, combined with the 
ensuing debate over the Labour's programme, resulted in a more robust desire on the part of some to reassert their rights and powers to influence internal discussion within the party's federal structures, most obviously the Annual Conference.

Organisational issues became the subject of intense factional debate within the party and this inevitably influenced the development of strategy. Percy Clark, now Director of Publicity continued to work closely with the prime minister and key campaign advisers. Wilson's retirement in 1976 marked a significant turning-point in the party's strategic development. A committed student of public opinion polling, the prime minister had supported an ambitious market research programme from pollsters MORI prior to the two general 1974 elections. ${ }^{55}$ The busy policy agenda of Wilson's successor Jim Callaghan combined with the need to manage a precarious Commons' majority left comparatively little time for strategic matters. He remained distant from a headquarters now presided over by General Secretary Ron Hayward, a tribune of the party's grassroots' left and an official weary of professional consultants. Following the 1979 election defeat, marketing advisers such as Tim Delaney and Edward Booth-Clibborn expressed disatisfaction about their effective isolation from the central decision-making structures within the campaign organisation. ${ }^{56}$

It is ironic that the most traumatic Labour campaign of modern times, in 1983, was also the first in which the party formally retained the services of an advertising agency. That said the relative distance of the firm, Johnny Wright and Partners, from the party's albeit incoherent decision-making structures limited their effectiveness. ${ }^{57}$ Nor did Wright have continuous access to Labour's own market research deliberations. These organisational problems were closely linked to political factors and, in particular, ongoing factional divisions within the party. These were in turn exacerbated by the then leader Michael Foot's personal preference for not playing a central role in the management of strategy. 
Foot's enthusiasm for the practical rather than managerial side of campaigning created a vacuum. Harold Wilson had been the link person at the centre of an uneasy alliance he had in effect created. The situation had arisen because Labour's National Executive Committee system, traditionally responsible for campaigns, had been in effect supplemented by a network of strategic advisers. The latter often worked with individuals, notably the leader, rather than to official structures. Though Foot did support the use of marketing expertise, his relatively low-key organisational role made effective decision-making difficult. The problem was exacerbated by the lack of a core group of leader aides and party officials able to execute committee decisions and liase with outside advisers. The resulting campaign was thus paralysed before it started. ${ }^{58}$

The experience of the 1983 campaign defeat greatly influenced new leader Neil Kinnock. He made the rejuvenation of campaign organisation a major priority. His leadership would see the party's embrace of political marketing technique. More profoundly for this social democratic organisation, managerialist thinking also began to inform its approach to electioneering. Kinnock's reform of the party came in two major phases. During the run-up to the 1987 campaign, the first stage saw the reintegration of professional expertise into party structures now overseen by a new Campaign Strategy Committee. ${ }^{59}$ To ensure decisions were implemented, the headquarters at Walworth Road were completely reorganised in 1985. These changes amounted to the most complete overhaul since 1918 and were even greater than those implemented in the early 1960s. A new four person Directorate was installed to assist the recently appointed General Secretary Larry Whitty. The only outsider to join this team, Peter Mandelson, took over a publicity portfolio now redesignated as Campaigns and Communications. ${ }^{60}$ 
Soon after Mandelson took charge he commissioned advertising consultant Philip Gould to investigate how the party's political communications might be improved. Following a critical report, Gould set up the SCA to help develop campaigns. ${ }^{61}$ Consisting of sympathetic professionals drawn from marketing, the Agency was central to party preparations for the 1987 general election. As such it was little different to the informal advisory panels that had helped Morrison in the 1930s and Wilson in the 1960s and 1970s. The SCA also played a critical strategic role following the 1987 defeat. It had a central role in organising and presenting market research findings that proved to be central to Labour's so-called Policy Review. As its title suggests the Review was a wide-ranging process that cumulatively served to firmly reposition the party towards the right. Partly inspired by his opposition to what he believed to be the increasing power of Labour's 'public relations people', leading left-winger Tony Benn mounted an unsuccessful challenge for the leadership in 1988. Though he anticipated the far reaching consequences of the reforms being proposed the scale of his defeat further underlined the problems facing dissenters within the party at the time.

Following the Review, and the disappointment of the 1992 election defeat, Labour continued to use marketing and advertising expertise. This was in spite of a barrage of criticism from many grassroots' members and even Shadow Cabinet ministers such as John Prescott. Following the defeat Prescott denounced the Shadow Agency as the 'beautiful people'. Initially key strategists who had worked so closely with Kinnock, notably Mandelson and Gould, were isolated under the new leadership of John Smith. Smith, however, consolidated the modernisation process in his brief tenure as leader between 1992-94 by reforming the party's candidate selection procedures. He, like successor Tony Blair, was adept at using the media to mobilise opinion within a greatly changed organisation. During this period much was made of the party's 'spin' doctors' ability to manipulate debates. 
The election of Tony Blair as leader in 1994 and Labour's subsequent victory in 1997 did little to diminish the considerable speculation as to these actors' supposed power to subvert and control every facet of the organisation and its business. In a much reported 1996 interview, Shadow Cabinet member Clare Short made public her disquiet about the supposed power of the 'people in the dark' advising Blair. Short's comments reflect a widespread concern both within and without her party that those charged with managing a politician's media relations, the so-called 'spindoctors', now hold a privileged and influential position. This they do with little apparent accountability and despite a burgeoning public profile.

\section{Other Parties.}

The comparative poverty and small size of the other British parties has meant that the Conservatives and Labour are responsible for most of the major innovations in political communication. There have, nevertheless, been times when the less funded and staffed organisations have made significant breakthroughs in campaign terms. During the 1929 general election the Liberals, for instance, broke with precedent when they began advertising in the press. The following decade the party once again set a precedent by becoming the first to hire an advertising executive to manage its publicity campaigns. The official in question, William Allison, joined Liberal headquarters direct from the leading agency J. Walter Thompson in 1937. ${ }^{62}$ More recently the party challenged conventional wisdom when, during the 1974 general elections, it took put advertising in national newspapers. Following legislation, politicians had assumed this was an illegal act. By their actions, the Liberals forced a change that led to the larger parties spending huge amounts on print advertising in the 1980s. That decade saw the Liberals' then allies in the newly formed Social Democrat Party experiment with professional direct marketing techniques. Through the use of personalised mailshots the SDP was able to build its membership base and raise not insubstantial funds. During the 1985 by-election in the huge rural seat 
of Brecon and Radnor, the Liberal/SDP Alliance demonstrated its mastery of direct marketing and niche targeting in an ultimately successful campaign. ${ }^{63}$

In recent years there has been a rise in minor party and independent parliamentary candidates. Most rely on traditional grassroots' work, the occasional Party Election Broadcast and new media forms to put across their message. Others however have attempted to emulate the approach of the larger parties. During its relatively successful European election campaign of 1989, the Greens employed advertising experts to help create a memorable Broadcast. In the 1992 general election the Natural Law Party became, in spending terms, the fourth largest competitor when it funded a major if ineffectual print and outdoor advertising campaign. During the subsequent campaign of 1997 the Referendum Party led by the billionaire businessman Sir James Goldsmith outspent all but the two largest parties. Before its demise the Referendum organisation brought one notable innovation to British politics: the campaign video, copies of which were sent to millions of householders.

\section{Conclusions.}

Three key stages in the development and transformation of British political communication have been identified. In discussing what have been termed the mass propaganda, media campaigning and political marketing the emphasis has been on the changing relationship between the party and electorate rather than any media or technological innovations. The growing use of market research as a feedback mechanism is central to understanding how political communication has developed over the course of the Century. That said there is sometimes a tendency on the part of the politicians and media to inflate their own importance as innovators or actors. Consequently it is important to recognise that while there have been major changes in the way campaigns are now conducted, there are some significant continuities in practice and theorising. Visual media such as film and posters began to play an 
influential electoral role during the inter-war period. In the same era, strategists started to talk about the importance of 'image', advertising and the psychology of the electorate. Interest in these and other phenomena intensified following the Second World War with the arrival of the so-called 'consumer society'. More recently the terms 'image maker' and 'spin doctor', both obvious manifestations of a managerial approach, have come to dominate modern political discourse. Arguably the 1992 general election was something of an electoral watershed because both major parties subscribed to a marketing driven strategy.

Political communication, most obviously in the form of campaigning, is concerned with more than just electioneering. It forms the civic link between the people and their representatives. Marketing and media methods have transformed the relationship in various ways. Most crucially the views of key sections of uncommitted voters, as determined by public and private opinion polling research, now play an influential role in the respective parties' preparation for a campaign. Furthermore effective political communication is not only about persuading the mass of public opinion but also seeks to mobilise and manage dissent inside the organisation. The increased mediation and marketisation of politics has further centralised power within leaderships to the detriment of rivals within the party. Indeed this change, rather than any improvement in voter persuasion, maybe the most significant outcome of the increased professionalisation of political communication.

The trend towards the centralisation of power within party leaderships can be seen in a variety of ways. With 'New' Labour there has been a downgrading of the party's traditional federal structures, most obviously the Annual Conference and its National Executive Committee. The rise of new policy fora in place of conference or executive debates has enabled the leadership to effectively manage discussion and outcomes. It seems highly likelihood that the General Secretary, the party's chief 
executive, will ever again publicly criticise the parliamentary leadership in a way that happened during the 1970s. The mass membership has become increasingly peripheral to discussions. Their input into policy is highly marginal when compared with the influence wielded by New Labour's advertising, market research and public relations consultants. Similarly the Conservative leader William Hague has embarked on an ambitious programme of party organisational reform which draws on his own as a management consultant and the business acumen of his aides and advisors. Even the Liberal Democrats, the most federal of the main national parties, is to a large extent guided by its new leader Charles Kennedy. Kennedy's reported interest in developing a more consensual approach to the running of the party suggests an open-minded outlook but nevertheless reveals the residual powers now invested in his leadership. 
${ }^{1}$ Austin Mitchell, Election '45: Reflections on the Revolution in Britain (London: Bellew/Fabian Society, 1995), p.42.

${ }^{2}$ Pippa Norris et al., On Message (London: Sage, 1999).

${ }^{3}$ Robert Michels, Political Parties: A Sociological Study of the Oligarchical Tendencies of Modern Democracies (New York: Free Press, 1911); Leon Epstein, Political Parties in Western Democracies (London: Pall Mall, 1967); Angelo Panebianco, Political Parties: Organization and Power (Cambridge: Cambridge University Press, 1988).

${ }^{4}$ Richard Rose, The Problem of Party Government (London: Macmillan, 1974), p.90.

${ }^{5}$ R.B. McCallum and Alison Readman, The British General Election of 1945 (Oxford: Oxford University Press, 1947); Mitchell, Election '45, pp.41-80.

${ }^{6}$ H. G. Nicholas, The British General Election of 1950 (London: Macmillan, 1951); David Butler, The British General Election of 1951 (London: Macmillan, 1952); David Butler, The British General Election of 1955 (London: Macmillan, 1955).

${ }^{7}$ David Farrell, 'Campaign Strategies and Tactics', in Lawrence LeDuc et al.(eds) Comparing Democracies: Elections and Voting in Global Perspective (Thousand Oaks, California: 1996), 160-183.

${ }^{8}$ Pippa Norris, Electoral Change since 1945 (Oxford: Blackwell, 1997), pp.193211.

9 Jay Blumler and Dennis Kavanagh, 'The Third Age of Political Communication: Influences and Features', Political Communication, 16, 209230.

${ }^{10}$ Avraham Shama, 'The Marketing of a Political Candidate', Journal of the Academy of Marketing Sciences, 4 (1976), 764-777.

${ }^{11}$ Dominic Wring, 'Political Marketing and Party Development: a "Secret" History'; European Journal of Marketing, 30 (1996), 100-111.

${ }_{12}$ M. Ostrogorski, Democracy and the Organisation of Political Parties (Chicago: Quadrangle, 1902).

${ }_{13}$ Neal Blewett, The Peers, the Parties and the People: the General Elections of 1910 (London: Macmillan, 1972), p.312.

${ }_{14}^{14}$ John Antcliff, The Politics of the Airwaves, History Today, (1984), March.

15 Timothy Hollins, The Presentation of Politics: the Place of Publicity, Broadcasting and Film in British Politics, 1918-39 (Leeds University: Unpublished PhD, 1981).

${ }^{16}$ Dominic Wring, 'From Mass Propaganda to Political Marketing: the Transformation of Labour Party Election Campaigning' in Colin Rallings et al.(eds) British Parties and Elections Yearbook 1995 (London: Frank Cass, 1996), 105-124.

${ }_{17}$ Harold Croft, $A$ Handbook of Party Organisation (London: Labour Party, 1931). 
18 Timothy Hollins, The Presentation of Politics, p.37.

19 Wring, 'From Mass Propaganda to Political Marketing', p.109.

20 Bernard Donoghue and George W. Jones, Herbert Morrison: Portrait of a Politician (London: Weidenfeld \& Nicolson, 1973), pp.209-211.

${ }^{21}$ Graham Wallas, Human Nature in Politics (London: Constable, 1948).

${ }^{22}$ Fielding, S., Thompson, P. and Tiratsoo, N., England Arise!: The Labour

Party and Popular Politics in 1940s Britain (Manchester: Manchester University Press, 1995), p.8.

${ }^{23}$ Colin Seymour-Ure, The British Press and Broadcasting since 1945 (Oxford: Blackwell, 1996).

${ }^{24}$ David Butler and Richard Rose, The British General Election of 1959 (London: Macmillan, 1960), p.17.

${ }^{25}$ Richard Rose, Influencing Voters: A Study of Campaign Rationality (London: Faber and Faber, 1967).

${ }^{26}$ David Butler and Anthony King, The British General Election of 1964 (London: Macmillan, 1965); Richard Rose, in Butler and King, The British General Election of 1964; Lord Windlesham, Communication and Political Power (London: Jonathan Cape, 1966).

${ }^{27}$ Andrew Taylor, 'The Conservative Party, Electoral Strategy and Public Opinion Polling, 1945-64', in Charles Pattie et al.(eds) British Parties and Elections Review Volume 7 (London: Frank Cass, 1997).

${ }^{28}$ Windlesham, Communication and Political Power.

${ }^{29}$ Rose, Influencing Voters; Dennis Kavanagh, Election Campaigning: the New Marketing of Politics (Oxford: Blackwell, 1995).

${ }^{30}$ Andrew Roth, Sir Harold Wilson: Yorkshire's Walter Mitty (London:

Macdonald and Jane's, 1977), p.233.

${ }^{31}$ Michael Cockerell, Live from Number 10: The Inside of Prime Ministers and Television (London: Faber and Faber, 1989), p.248.

${ }^{32}$ Margaret Scammell, Designer Politics: How Elections Are Won (Hampshire: Macmillan, 1995).

${ }^{33}$ Hilde Himmelweit et al., How Voters Decide (Milton Keynes: Open Universty Press, 1981).

${ }^{34}$ Scammell, Designer Politics, pp.65-70; Kavanagh, Election Campaigning. pp.57-65.

${ }_{35}$ Scammell, Designer Politics, p.76.

${ }^{36}$ Nicholas O'Shaughnessy, The Phenomenon of Political Marketing (Hampshire: Macmillan, 1990), p.212.

37 Adrian Sackman, 'The Learning Curve Towards New Labour: Neil Kinnock's corporate party 1983-92', European Journal of Marketing, 30 (1996), 147-158.

${ }^{38}$ David Butler and Dennis Kavanagh, The British General Election of 1987 (Hampshire: Macmillan, 1988). 
39 David Butler and Dennis Kavanagh, The British General Election of 1992 (Hampshire: Macmillan, 1992).

${ }^{40}$ Dave Hill, Out for the Count (Hampshire: Macmillan, 1992).

${ }^{41}$ David Butler and Dennis Kavanagh, The British General Election of 1997 (Hampshire: Macmillan, 1997).

${ }^{42}$ Richard Cockett, 'The Party, Publicity and the Media', in Anthony Seldon and Stuart Ball, eds, Conservative Century: The Conservative Party since 1900 (Oxford: Oxford University Press, 1994), 547-577.

${ }^{43} \mathrm{~J}$. Ferris and U. Bar-Joseph, 'Getting Marlowe to Hold his Tongue: the Conservative Party, the Intelligence Services and the Zinoviev Letter', Intelligence and National Security, 8 (1993), 100-137.

${ }^{44}$ Scammell, Designer Politics, p.31.

${ }^{45}$ Cockerell, Live from Number 10, p.15.

${ }^{46}$ Cockerell, Live from Number 10, p.24.

47 Windlesham, Communication and Political Power.

${ }^{48}$ Cockett, 'The Party, Publicity and the Media', pp.569-570.

49 Rose, Influencing Voters, p.70.

${ }^{50}$ Cockerell, Live from Number 10., p.71.

${ }^{51}$ Mark Abrams, Richard Rose with Rita Hinden, Must Labour Lose? (London: Penguin, 1960).

${ }^{52}$ Butler and King, The British General Election of 1964, p.57.

${ }^{53}$ David Butler and Anthony King, The British General Election of 1966 (London: Macmillan, 1966).

${ }^{54}$ David Butler and Michael Pinto-Duschinsky, The British General Election of 1970 (London: Macmillan, 1971).

55 Robert Worcester, British Public Opinion (London: Blackwell, 1991), pp.5152.

${ }^{56}$ Kavanagh, Election Campaigning, p.86.

${ }^{57}$ David Butler and Dennis Kavanagh, The British General Election of 1983 (London: Macmillan, 1984), pp.57-58.

${ }^{58}$ David Butler and Dennis Kavanagh, The British General Election of 1987 (Hampshire: Macmillan, 1988), p.50.

59 Paul Webb, 'Election Campaigning, Organisational Transformation and the Professionalisation of the Labour Party', European Journal of Political Research, 18 (1991), 9-28.

${ }^{60}$ Butler and Kavanagh, The British General Election of 1987, p.59.

${ }^{61}$ Colin Hughes and Patrick Wintour, Labour Rebuilt: The New Model Party (London: Fourth Estate, 1990); Philip Gould, The Unfinished Revolution: How the Modernisers Saved the Labour Party (London: Little Brown, 1998).

${ }^{62}$ Timothy Hollins, The Presentation of Politics, pp.213-214.

${ }^{63}$ Kevin Swaddle, 'Hi-Tech Elections: Technology and the Development of Electioneering since 1945', Contemporary Record, (1988), Spring. 